\title{
EDITORIAL
}

\section{Time to stand up}

We recall Andrei Sakharov's contributions to physics and his social and political activism and find

that his ideas remain as relevant and inspiring today as 50 years ago.

Cf Every scientist
should undoubt-
edly muster
sufficient courage
and integrity
to resist the
temptation
and habit of
conformity

What does the News \& Views on charge-parity $(\mathrm{CP})$ violation and Feature on the fusion experiment at ITER in this issue have in common? The question may sound like a cheap clickbait, but serendipitously having these two pieces in our June issue prompted us to ponder on the life and legacy of a famous physicist and activist: Andrei Sakharov, whose scientific ideas and views on societal challenges are acutely relevant 50 years on.

Sakharov had a tumultuous life. After the Second World War ended he went to graduate school to study theoretical particle physics under Igor Tamm (Nobel Prize winner for the co-discovery of Cherenkov radiation), but in 1948 Tamm and his students were enlisted to help Yakov Zeldovich (perhaps better known for his contributions to cosmology) in the development of a hydrogen bomb. Sakharov produced the design that was ultimately used to build the first Soviet hydrogen bomb, successfully tested in 1953. In 1950, Tamm and Sakharov came up with the idea of a thermonuclear fusion reactor, the tokamak - the type of reactor used at ITER.

Sakharov continued to make key contributions to the Soviet hydrogen bomb programme, but in the late 1950s he recognized terrible consequences of nuclear testing in the atmosphere. He started to oppose more nuclear tests and after the 1963 Partial Test Ban Treaty, Sakharov returned to fundamental research. He dived straight into cosmology to study the problem of the matter-antimatter asymmetry in the Universe. In 1967, he came up with three conditions that would lead to an initially symmetric universe ending up with more matter than antimatter, now known as the Sakharov conditions. One of these is the violation of CP-symmetry, which was recently observed in the decay of $\mathrm{D}^{0}$ mesons as explained by Alexander Lenz in a News \& Views article in this issue.

In the late 1960s Sakharov's activism started to develop. Interestingly, his first battle was on behalf of biologists. Soviet biology was in a poor state owing to the influence of Trofim Lysenko, an agronomist who had gained the undeserved support of the Soviet regime in rejecting genetics in favour of his own theory. Sakharov, who had earned some understanding of genetics from his studies of the effects of radiation on biological tissues, openly opposed Lysenko and his pseudo-scientific views in the Soviet Academy of Sciences. His opposition contributed to the rebirth of genetics and biological sciences in the Soviet Union.

Sakharov's activism went beyond science and in 1968 he published an essay, Reflections on Progress, Peaceful Coexistence, and Intellectual Freedom ${ }^{1}$, in which he outlined "the grave perils threatening the human race - thermonuclear extinction, ecological catastrophe, famine, an uncontrolled population explosion, alienation, and dogmatic distortion of our conception of reality," and proposed a number of recommendations for tackling these issues.

In the 1970s Sakharov grew more vocal about the issue of human rights and consequently less agreeable to the Soviet regime. In 1975, he was awarded the Nobel Prize for Peace, but was not allowed to travel to the Nobel ceremony, attended by his wife instead. His relentless activism was becoming a serious problem for the regime, so in 1980 Sakharov was exiled to Gorky, a city on Volga river, where he spent 7 years under constant surveillance. However, undeterred, he continued to criticize the regime, going on several hunger strikes. With the Perestroika movement, Sakharov was allowed to return to Moscow, gradually regaining his status; sadly he passed away in 1989, months before the fall of the communist regime.

Sakharov's foresight proved disturbingly accurate. Over 50 years ago ${ }^{1}$ he warned about dangers such as climate change due to high-levels of carbon dioxide, pollution due to the release of dangerous chemicals, the development of antibiotics resistance and the disappearance of biodiversity. The climate emergency we face today makes a clear case why scientists are worth listening to. In today's world in which inequality, discrimination, the violation of human rights and the distortion of truth remain insufficiently addressed, Sakharov's writings are still pertinent and his life of activism is as inspiring as ever.

Given the current climate it is timely to remember Sakharov's words: "Every scientist should undoubtedly muster sufficient courage and integrity to resist the temptation and habit of conformity"2 and think how each of us can stand up for science and society.

1. Sakharov, A. Thoughts on progress, peaceful coexistence and intellectual freedom. New York Times (22 Jul 1968).

2. Sakharov, A. The responsibility of scientists. Nature $291,184-185$ (1981). 